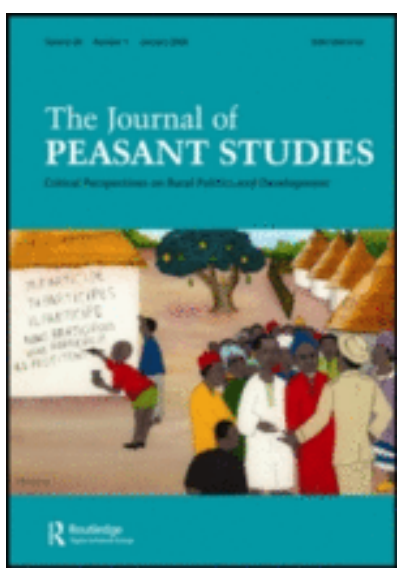

\title{
Do Women Like to Farm? Evidence of Growing Burdens of Farming on Women in Rural India
}

\begin{tabular}{|r|l|}
\hline Journal: & Journal of Peasant Studies \\
\hline Manuscript ID & FJPS-2020-0080.R1 \\
\hline Manuscript Type: & Regular research article \\
\hline Keywords: & $\begin{array}{l}\text { women in agriculture, preparatory work, decision-making, control over } \\
\text { incomes, rural India }\end{array}$ \\
\hline \multicolumn{2}{|l}{} \\
\hline
\end{tabular}

\section{SCHOLARONE ${ }^{m}$ \\ Manuscripts}




\section{Do Women Like to Farm?}

\section{Evidence of Growing Burdens of Farming on Women in Rural India}

\section{Introduction}

There is a prominent analytical divide surrounding women's labour contributions to the agricultural sector in India, and incongruent official statistics is largely responsible for this (Abraham 2013; Siddiqui et al. 2017). Women's share in the overall labour force has declined in the last census (Mehrotra and Sinha 2017), while 65\% of the total female workforce (as against $42 \%$ of the male workforce) is still engaged in agriculture (Pattnaik et al. 2018). This extraordinary concentration of women's labour in agriculture is termed as the 'feminization' of agriculture (GOI 2018). Yet, interpreting this 'feminization' and providing concrete evidence through numerical data are not as straightforward, even though such data provide a starting point. Earlier, scholars (see, for example, Chandrasekhar and Ghosh 1999) had pointed out that this process is driven by distress-induced rural male outmigration and casualization of rural workforce ${ }^{1}$ as compared to other parts of Asia where the general trend is for rural male labour to shift from low-paid agriculture to better-paid industrial or tertiary sector jobs (Horton 1996; FAO 2003). While men perform non-farm activities, rural women's labour becomes more focused on agricultural activities. This leads to questioning the nature and type of feminization to assess whether women are empowered or disempowered by their increased involvement in agriculture. This paper also probes if this feminization empowers women's decision-making ability in agriculture and at the household level. A related challenge is the redefinition of 'agricultural work' to reflect the myriad activities that women perform in the field. The limited literature that notes the declining proportion of women's labour in agriculture, or de-feminization of agriculture (Abraham 2013; Mehrotra and Sinha 2017), relies upon official statistics, which fail to capture 'preparatory work', 'pre-production work', and work as 'helpers', and consequently do not consider women's full labour contributions to agriculture. One can surmise that policymakers' perception of 'activity status' is gendered, and a lack of

\footnotetext{
Most urban jobs that rural male migrants find are insecure and poorly paid (Shah and HarrissWhite 2011), causing many to shuttle between agriculture and non-agricultural informal employment (Binswanger-Mkhize 2013).
} 
attention to women's involvement in such activities can omit crucial gendered dimensions.

The paper is divided into six sections. Following the introduction, the second section conceptualizes the paper with the help of past studies. Section three provides the rationale behind selecting the study areas and the methodology for analysis. The fourth section discusses women's extensive labour contribution in field vis-à-vis their autonomy in decision-making. Analysis based on class, caste, and region is presented thereafter. Section five presents the narratives of women who note their preferences and aspirations, and alternative opportunities, if any. The final section offers recommendations.

\section{Feminization of Indian agriculture: A reality check}

A discussion on the cause of feminization of agriculture in India reflects both extremes of political alliance. Those viewing from a neoliberal perspective emphasize the demand or the pull factor that draws women into agriculture. In contrast, Marxist scholars lay importance on the push factor that is driving men out of dysfunctional agrarian systems. Agricultural growth led by the Green Revolution of the 1960s raised a demand for labour (Walker and Ryan 1990). Growth in the crop sector influenced male migration and income diversification towards the non-farm sector, and with this women got control over agriculture (Azad et al. 1985; Bennet 1992; Chand, Sindhu, and Kaul 1985). The contradictory views discuss that women's increased participation in farmwork does not reflect upward mobility, but is merely the result of increased pauperization of smallholders (Agarwal 1985; Byres 1981; Duvvury 1989). The Green Revolution also increased the need for cash income to cover the cost of technological inputs which threw women into the fields or work as unpaid family labourers. Recent studies also emphasize agrarian crisis and distress-led male migration as primary causes of this feminization (Agrawal and Chandrasekhar 2015; Garikipati and Pfaffenzeller 2012; Lahiri-Dutt 2014).

As per official statistics, the share of women as cultivators declined conjointly with an increase in agricultural labourers during 1961 and 1981. The decline was due to increased pauperization of the Indian countryside during this period, and not because women withdrew from productive work due to an increase in income during the Green Revolution (Duvvury 1989). From 1981 to 2011, the share of female cultivators declined from $37 \%$ to $24 \%$, but their share as agricultural labourers remained almost 
constant, falling only three percentage points from $44 \%$ to $41 \%$, while the share of men as cultivators and agricultural labourers declined (Pattnaik et al. 2018).

While official surveys do not capture the actual contributions of women, time-use surveys reveal smaller gender gaps. Hirway and Jose (2011) show that women's work is more scattered through the crop value chain and around the household. They undertake multiple jobs and the burden of their unpaid work is a constraint on their accessing other job opportunities. Around 35\% female and 30\% male workers performed more than three activities outside of home, while around $6 \%$ female workers performed more than five activities. Performing multiple jobs restrict women within low-wage, manual, and low-productive activities, limiting their upward mobility in the labour market (Jain 1996; Satyavathi, Bharadwaj, and Brahmanand 2010). Therefore, feminization of agriculture in India is evidenced in the higher rate of concentration of women as agricultural wage labourers which is mainly driven by distress in this sector. How far does earning cash incomes from working in others' fields empower women in terms of decision-making or bargaining power at home and on farm remains unclear. The significant gap between male and female wages in agriculture (Agarwal 2014) continues to disadvantage women as do the remarkable wage gaps between the farm and non-farm sectors (Himanshu and Kundu 2016). It remains doubtful whether feminization of agricultural labour translates into managerial feminization of agriculture (as distinguished by Gartaula, Niehof, and Visser 2012 in case of Nepal) to make women agents of change in the existing gender-power landscape in rural areas. Research has established that an over-representation of women in agricultural wage labour limits their work to the 'peripheral' segment, prevents any form of skill development, and denies them decision-making power (De Schutter 2013). Decisionmaking or capacity to make 'strategic' choices is a process towards empowerment (Kabeer 2016), not just an individual's rights over assets (Alkire et al. 2013; Ibrahim and Alkire 2007). Women's economic empowerment is a prerequisite for household food security, inclusive growth, and gender equality (Agarwal 2011; Das et al. 2015; Duflo 2005). Any increase in women's participation in the workforce might seem to bear potential for improving their quality of life, but working conditions in the agricultural sector are unregulated and the possibility of achieving parity of income and status with their male counterparts is blocked by structural challenges. One such challenge is that men make major decisions related to farm management (LastarriaCornhiel 2006). Other challenges include the fact that only a few women in rural India 
enjoy property or land rights, or own or lease the land they work on (Agarwal 2012), or even receive recognition for their work (Deere 2005). This gendered nature of control over productive resources has been noted elsewhere by scholars as having undermined women's autonomy. Concluding her research on feminization of agriculture in Africa, Lastarria-Cornhiel $(2006,18)$ observes:

Neo-liberal policies have intensified and extended reproductive (and unpaid) labour. Since the gender division of labor assigns reproductive and domestic work to women, their workday has been extended because of the decline of social services and the rise in costs of food and other household basic needs.

Even if household income increases as a result of their farm work, women generally have little or negligible control over deciding how it is spent (Duvvury 1989; Garikipati 2006). Despite additional responsibilities, women single-handedly run the household and care for children and the elderly (Subhanil 2011). Thus, over-representation of women in agriculture is often associated with tenuous and underpaid employment, which is ultimately disempowering (Kelkar and Wang 2007).

This bleak scenario raises the following question: Has feminization of Indian agriculture improved women's well-being and autonomy? Specifically, is their added participation leading to increased decision-making or is it only adding to their burden? What do women feel about the situation, and do they want to continue working in agriculture? Do they choose this work or are they driven by economic compulsions? How do other social determinants, such as the caste structure, influence their participation? Finally, how should the government respond to this emerging phenomenon? To seek answers to these questions we carried out an extensive household survey during 2015-16.

\section{Locating the study and methods}

For the purpose of our study, we considered the two Indian states of Gujarat and West Bengal because of their diverse agro-climatic and socio-economic conditions as well as disparate cropping patterns. The states are dissimilar from each other in many ways: Gujarat's per capita net income is much higher than West Bengal's, ${ }^{2}$ and from 2011-

\footnotetext{
2 During 2017-18 the per capita income was Rs 131,853 ( USD 1,803) for Gujarat and Rs 65,978 ( USD 902) for West Bengal; the national average during this time was Rs 86,668 $(\sim 1,185)$ (GOI 2019).
} 
12 to 2016-17 the annual agricultural income grew at 3.3\% compared to West Bengal's $1.7 \%$. With regard to cropping pattern, Gujarat ranks first in cotton and groundnut production, whereas West Bengal tops paddy and jute production in India. Gujarat is a cash-crop-dominated agricultural economy, ${ }^{3}$ and the degree of commercialization and market interference too are relatively better here than West Bengal. ${ }^{4}$ However, the rate of rural poverty in both states remains the same at around $22 \%$, confirming that irrespective of cropping pattern rural distress is acute.

A decline in female work participation rate (FWPR) is detected by comparing data of 2011 and 2017.5 Gujarat faced a steeper decline in rural FWPR, from $28 \%$ to $17 \%$, than West Bengal, from $20 \%$ to $15 \%$ (GOI 2014, 2019). Concentrating on individual sectors, in Gujarat the decline is highest in agriculture, from $86 \%$ to $81 \%$. However, compared to $5 \%$ in 2011, FWPR in the manufacturing sector increased slightly to $6 \%$ in 2017 . Contrary to Gujarat's trend, during the same period FWPR in West Bengal increased in the agricultural sector from $41.7 \%$ to $51.9 \%$. Though the overall FWPR has declined in the state, the share of female workers in agriculture has increased, but declined in the manufacturing sector, from $42.2 \%$ in 2011 to $25 \%$ in 2017 . This decline needs careful analysis. The probable causes could be demonitization, introduction of GST, and crisis especially in the jute industry. The impact of GST has been greatly felt as West Bengal comprises a large portion of unregistered and submerged informal businesses (Business Standard, April 8, 2019; First Post, April 29, 2019). Recent years have however seen a return of female workers from other non-farm sectors to agriculture in the state.

\subsection{Selection and sampling}

${ }^{3}$ The total area under foodgrain constituted around $65 \%$ of the gross cropped area (GCA) in West Bengal compared to $25 \%$ in Gujarat in 2018. Major cash crops of Gujarat-cotton, groundnut, castor, and tobacco - together constituted around $40 \%$ of the total area in 2018. Major cash crops of West Bengal - jute, tea, sugarcane, and tobacco - collectively constituted only about $12 \%$ of area in 2017 (GOG 2019; GOWB 2018).

${ }^{4}$ This is evident from a number of factors. The marketed surplus of foodgrains in Gujarat was $97 \%$ in 2015 compared to $68 \%$ in West Bengal. Among oilseeds, the marketed surplus of groundnut in Gujarat was $95 \%$ as against $77 \%$ in West Bengal of mustard, the state's major oilseed (GOI 2019). The number of markets, an indicator of infrastructural development, show that the number of principal regulated markets in Gujarat (199) was greater than West Bengal (42). However, the submarket yards are quite high in West Bengal (415) compared to Gujarat (400).

${ }^{5}$ Authors' calculation based on unit level data from the NSS Quinquennial survey, 68th Round (GOI 2014) and Periodic Labour Force Survey (PLFS 2019). 
We selected four districts in each state based on a maximum-variation principle to capture the variations in local agro-climatic and agro-ecological contexts (Map 1). Using data from the 2011 Census, two villages in each district were selected, making it a total of eight villages in each state. In each of these 16 villages, a house-listing (census) exercise was conducted before selecting the sample and we found 3,235 households in Gujarat and 2,770 in West Bengal. By using a stratified-random sampling technique, we then selected 50 households from each village. In total, we interviewed 800 female farmers. Our questionnaire, finalized beforehand after phases of pilot testing, aimed at retrieving the 'hidden' gendered data that official statistics fail to extract (Chakravarty 2020).

\section{Map 1 Location of the study}

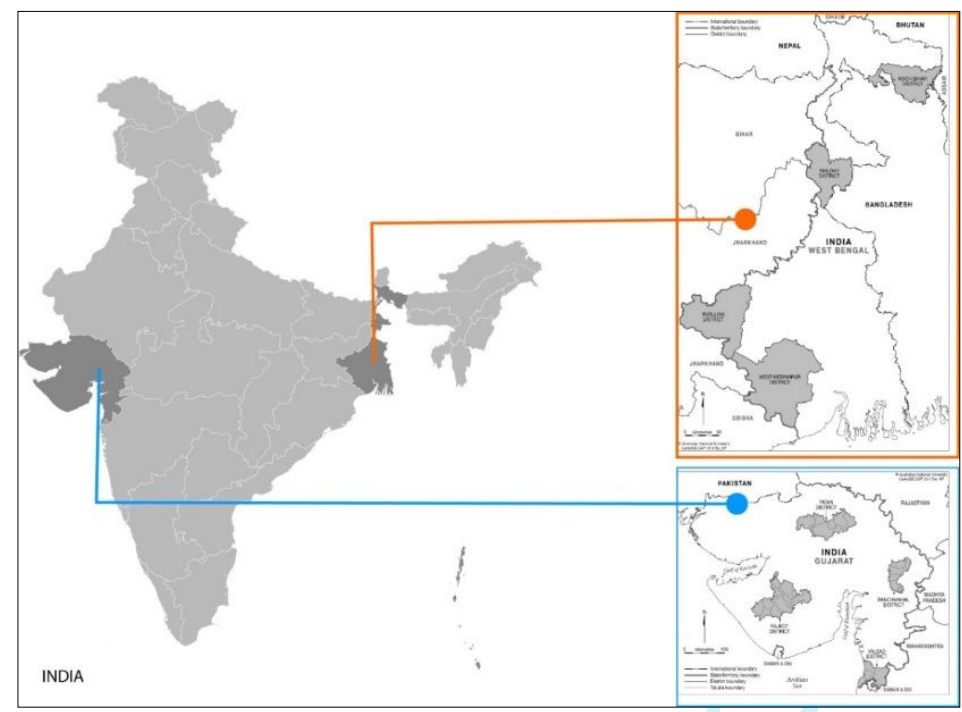

Source: Authors.

We only selected households owning some amount of land because these households had women in activity-performing and decision-making roles in agriculture. ${ }^{6}$ From each household, we selected the 'most involved woman in agriculture' as our respondent.

To add critical depth, we carried out extensive interviews with 28 female farmers about their views on work, perceptions of autonomy, and ideas about the future of farming in their areas. Insights from some interviews are included in this paper along with data generated by the questionnaire-based survey. Since the data are both quantitative and

\footnotetext{
${ }^{6}$ Of the total number of households, $80 \%$ in Gujarat and $71 \%$ in West Bengal owned land.
} 
qualitative in nature, mixed methods were used to analyse and gain a holistic picture of the status of the subjects and their perception as well as changing aspirations in the two agrarian states of India.

\section{Women's labour contributions and autonomy}

Our respondents were mostly illiterate $(60 \%$ and $49 \%$ in Gujarat and West Bengal, respectively) with a median age of 42 and 39 years in Gujarat and West Bengal, respectively. Since social structure in rural India (among Hindu communities) is defined mainly by caste categories, ${ }^{7}$ our sample consisted of women from different castes. Out of all women surveyed in Gujarat, the Other Backward Classes (OBCs) (47\%) constituted the largest single category, followed by Scheduled Tribes (STs) (29.4\%), Scheduled Castes (SCs) (6.2\%), and the general caste (17.4\%). In West Bengal, SCs comprised $37.7 \%$, followed by general caste (23.9\%), OBCs $(21.2 \%)$, and STs $(17.2 \%)$. The average size of landownership is synonymously hierarchical to caste categories in Gujarat as the average size of land owned was highest among general caste and least among STs. However, due to land reform and distribution of land to the landless, there was not much disparity in landownership across caste groups in West Bengal. Here, within our survey area, we did not come across medium or large landholders, unlike in Gujarat where all landholding categories were present.

\subsection{More work, less pay}

India's rural economy has diversified dramatically with an expansion of income sources of most landholders. During our survey, about $71 \%$ men and $74 \%$ women in Gujarat, and $65 \%$ men and $69 \%$ women in West Bengal, were engaged in more than one occupation. Again, this reflects information collected at the national level where men outnumbered women in work outside the agricultural sector almost by 4:1 in 2011-12 (Chand, Srivastava, and Singh 2017b). Women's involvement in sectors other than agriculture was almost negligible in our survey. Around $86 \%$ and $79 \%$ of women reported agriculture as their primary occupation in Gujarat and West Bengal, respectively. Only 6\% in West Bengal and 3\% in Gujarat reported non-agricultural

\footnotetext{
${ }^{7} \mathrm{OBC}$ are defined as socially and educationally backward classes who are economically relatively better compared to the SCs and STs. While SCs, also known as Dalits, face discrimination and social exclusion, and remain at the very bottom of the caste system, STs are officially the historically disadvantaged indigenous people in India.
} 
labour as their primary occupation. Women in non-agricultural manual selfemployment were only $4 \%$ in West Bengal compared to $2 \%$ in Gujarat. While women are engaged in NREGA in West Bengal, making salaried employment the major secondary occupation for surveyed women in the state, livestock and petty trade (shops) featured as major secondary occupations in Gujarat. In both states rural women are confined to work that is available within the peripheries of the village. As agricultural sector wages in India tend to be lower than urban, non-agricultural jobs, this confinement partly explains why on an average rural women, even though they work more, earn less than men. ${ }^{8}$

Analysis of wages in both states shows that agricultural wage is higher in West Bengal. It is possible that political factors such as peasant movements and labour unions contribute towards this. The average wage in our survey was Rs 233 ( USD 3 ) for men and Rs 154 ( $\sim$ USD 2) for women in West Bengal, and, in Gujarat, Rs 217 ( USD 2.97) for men and Rs 169 ( USD 2.31) for women. In addition, seasonal variations in wages were reported by surveyed women in Gujarat. In Patan, for example, wages rise to Rs 300 ( USD 4) during the peak season with a high demand for labour and falls to around Rs 50 ( $\sim$ US 68 cents) during the lean season. During this time men generally migrate from villages in search of cash incomes, leaving women to accept any available work in the village at low wages. The seasonal gap further widens the wage gap between those who stay back at villages (mostly women) and those who migrate (mostly men). The surveyed women do not see this wage differential as gender-based discrimination and state that since men do more and physically heavier work, their better wages are justified.

\subsection{Women as agricultural wage labour: Working in others' farms}

Women are involved primarily in agriculture either on farms owned by their family or as agricultural labour on farms owned by others. In our survey area women belonging to the upper caste do not engage in agricultural wage labour as their primary or secondary occupation, but for women from SC and ST communities this is their main subsidiary occupation, especially in West Bengal. Most women from the SC and ST communities in Gujarat work as agricultural wage labourers in other people's fields as

\footnotetext{
${ }^{8}$ The gap between farm and non-farm income of 1:3 in the mid-1980s widened to $1: 4.08$ by the mid-1990s and to 1:3.12 in 2011-12 (Chand 2017).
} 
their primary occupation. Working on others' fields has a cultural bias among the upper caste women-Darbar and Rajput women in Gujarat never work in others' fields. Besides culture, other reasons that influence the location of work include the size of the land: the smaller size of their land force SC and ST women to work in others' field as the primary occupation and in their family field as the subsidiary occupation. Scholars are concerned about how lucrative wage labour is for rural women (Agrawal and Chandrasekhar 2015; Chand, Srivastava, and Singh 2017a). For women, increasing labour hours widens the gender gap in income (Banerjee 1999) because it lowers cash income, devalues labour, renders them invisible in official data, and increases their work burden. Working as causal wage labourers with other women in similar situations may confer better bargaining strength. However, there is no concrete evidence to show that women's involvement in casual agricultural wage work has led to a decline in their reproductive responsibilities. In this study, most women from landowning households who worked as casual labourers reported that their reproductive chores in households remained unchanged. Improved cash incomes too did not translate into greater autonomy in their spending power or decision-making.

Women also tend to work in the fields of those belonging to their own caste, or exchange labour with same-caste households. Again, this restriction limits women's bargaining power to demand better wages because the employer and employee relation keeps changing, an observation also made by Rao (2011) in a study of south India.

\subsection{Women in crop production}

Women are involved in almost every type of activity associated with farming, from time-consuming, strenuous activities such as weeding and harvesting, storing grains post harvest, seed collection and preparation, and threshing, to minor activities (not 'minor' in terms of burden) such as drying seeds and grains, transporting various small items, and carrying food from home to the field. For particular crops only women perform the related tasks, such as extracting groundnut kernels (in Rajkot); preparing potatoes for planting (in Malda); extracting fibre from jute (in Cooch Behar); transplanting rice seedlings (across districts in West Bengal); winnowing wheat and pulses; and cleaning, preparing, and arranging farm products for sale, and drying agricultural products such as tobacco leaves (in both states). Lack of training or experience restricts the involvement of women in some customarily masculine activities, such as sowing mustard and castor bean seeds, an acquired skill few women 
have had the chance to learn. Overall the data for this study is in line with Baliyan (2016), which records that women in rural Uttar Pradesh performed menial agricultural tasks, while men performed almost all market-related activities, like buying agricultural inputs, hiring labour, and sale of output.

The present study confirms that more women than men participated in agriculture, but the proportion varied by region and women worked jointly with men in almost all major farm activities. In Gujarat women worked primarily in weeding and harvesting; in West Bengal they carried out a much wider array of tasks (Figures 1 and 2) such as land levelling, irrigating plants, weeding, harvesting, sowing seeds, and even transplanting. Mechanization is relatively advanced in Gujarat, which could be the reason for a lesser requirement of agricultural labour and the limited role of women's labour on farms (Akter et al. 2017). In our findings we saw groups of seven to fifteen farmers purchased land levellers and other farm machinery for communal use in Gujarat. In West Bengal land levelling was still done manually, sometimes with the assistance of buffaloes and oxen. Mechanization requires additional investment, the absence of which forces peasant households to involve women on farms and at times even children and the elderly. Other studies show that mechanization continues to displace women's labour (Agarwal 1981; Siddiqui et al. 2017; Satyavathi, Bharadwaj, and Brahmanand 2010). Jannatben, one our participants from Malda (West Bengal), confirmed this finding:

When we receive a good income the first thought is to buy a tiller or a wheat thresher, but the last thing that we can ever think of is buying equipment that can reduce the workload of women on farms. So, the purchase of equipment such as a paddy winnower, wheel hoe, or cono-weeder that helps in weeding are never the priority, though they are not that expensive.

Upper caste and Muslim women in both states reported that earlier they rarely worked on farms. Women from upper castes and higher landholding households are however in charge of keeping track of hired, especially female, labourers. Caste barriers to women's work participation in agricultural activities-other than weeding and harvesting - are stronger in Gujarat. Generally, besides caste restrictions on certain types of work, the economic strata of the family appear to be the major determinant in women's work participation. We found that in both states across caste groups women from smaller landholding households are more active in agriculture compared to higher landholding households. 


\section{Insert Figures 1 and 2 here $>$}

\subsection{Preparatory work}

Our questionnaire allowed respondents to identify which household member had the main responsibility for each task, and the case studies highlighted that even in jobs identified as male-centric, women were often involved as helpers. Thus, it may appear that women do less work and participate in a smaller range of farm activities, which is far from reality. Women make every necessary on- and off-farm arrangement for all farm activities. The preparatory work is arduous and time-consuming (Boxes 1 and 2), such as cooking food for the hired hands, but it is often overlooked by researchers and society. Past studies question if Indian women's unpaid work at home should be regarded as an 'economic activity' (Rawal and Saha 2015; Siddiqui et al. 2017), but not the work they undertake as 'helpers' in the agricultural sector. Although overlooked, they play the central role in Indian agriculture and at all stages of the cropping cycle, though their work is noticeable only in rearing livestock and preparing fields for sowing.

\section{$<<$ Insert Boxes 1 and 2 here $>>$}

\subsection{Decision-making and control over incomes}

Women's autonomy is used with the indicator of landownership and decision-making to examine their level of empowerment. With limited decision-making ability or low access to resources, it is more likely that women accept lower wages (SOFA Team and Doss 2011). However, if they manage households and also make major decisions within the private sphere, it reflects greater autonomy and independence in spite of increased workload, eventually leading to their empowerment (Singh, Singh, and Kumar 2013). Decision-making authority is used as an indicator of intra-household bargaining power to measure empowerment (Anderson, Reynolds, and Gugerty 2017; Doss 2013; Kabeer 2001; Mason 2005). If women have joint control over income and household decisions, more of the family's income is allocated to food, education, and improving health (Hyder et al. 2005; Meinzen-Dick et al. 2010). Presently, in making important household decisions in rural India women often play a subordinate role (Damisa and Yohanna 2007; Pal and Haldar 2016), but it is far from being universal, and their decision-making power is linked closely to their social and economic capital 
(Anderson, Reynolds, and Gugerty 2017; Balasubramanian 2013), that is, their access to property, financial assets, and engagement in the labour market (Doss et al. 2014; Quisumbing 2003).

In considering how women in the Indian agricultural sector participate in decisionmaking, our survey observes that women in rural India make many small, seemingly insignificant, decisions about day-to-day work, whereas their husbands or other male relatives make the more important decisions regarding farm management or sales of crops. In West Bengal, and more in Gujarat, women have little say in major decisions about farm management and the sale of agricultural products in markets (Figures 3 and 4). Cropping-related decisions are made alone by $8-10 \%$ women in West Bengal and 3-5\% women in Gujarat. In West Bengal women's sole decision on farm-related activities, such as the type of crop to be grown and the amount of crops to be sold, is higher among households cultivating vegetables.

\section{$<<$ Insert Figures 3 and 4 here $>>$}

Women's representation in farm-related decision-making, either jointly with male members or independently, was similar in both surveyed states, but for other activities it was much higher in West Bengal, such as decisions on the purchase or sale of animals, land, or other valuable household assets. If measured solely in terms of decisionmaking, women's empowerment appears to be better in West Bengal, but this does not necessarily translate into autonomy in farm-related decision-making. At the subregional scale, in Gujarat female participation in joint decision-making on farm-related issues was found to be better in tribal and less-developed regions (Panchmahal, with a $30 \%$ representation of tribals, and Valsad, with a 50\% representation) than the state's irrigated cash-crop-growing belt. Similarly, in West Bengal female participation in decision-making related to crop selection and sale of farm output and animals was better in the tribal belt and less-developed region of Purulia.

When rural women were asked why they hardly participated in making decisions on farm management, $48 \%$ of women in Gujarat and 39\% in West Bengal said their husbands were better equipped to make such decisions; another $23 \%$ in Gujarat and $27 \%$ in West Bengal said it was because they did not own land. Women are often underrepresented in rural organizations and institutions and poorly informed regarding their 
civic rights. This prevents them from having an equal say in decision-making processes and thereby reduces their ability to participate in collective activities. Awareness of government subsidy schemes for farmers was higher in West Bengal (22\%) than in Gujarat (9\%). However, female participation in agricultural extension services such as attending village- or district-level meetings related to land was low to the point of being insignificant.

Deeply rooted cultural and societal beliefs about idealized relationships between women and men hold women back from participating in farm-related decision-making. However, after farm, livestock, household activities, and sometimes taking care of the shop, women have no time left to travel and attend government rural education programmes or learn new farming techniques or technology (Box 3). Women are likely to be the chief decision-maker at home, especially the education and health of family members; informal discussions suggest that most men, especially in Gujarat, consider education and health part of the household domain and a woman's duty to fulfil, failing which she fears reprimand.

\section{$<<$ Insert Box 3 about here $>>$}

Two major observations emerge from the aforementioned discussion on gendered norms. First, rural women in West Bengal have greater involvement in solo decisionmaking and could be relatively more empowered in this regard. Besides culture, different social and political processes might have influenced gender roles and relations in both states. During our survey, it was evident that women in West Bengal were more politically aware and more vocal about their concerns. Successful implementation of family planning and organized grassroots mobilization (as noted by Maharatna 2007) might have played an important role in making women somewhat better involved in the public sphere.

Second, women in tribal and economically less developed regions are involved in decision-making. It is likely that disadvantageous groups have fewer cultural stereotypes tying them to gender-oppressive traditions. During the survey, women from these groups generally participated without restrictions, displayed lesser inhibitions, and were less class consciousness.

\subsection{Migration and decision-making}


Short-duration migration is a prominent feature in both the surveyed states; in Gujarat $52 \%$ of households and $42 \%$ in West Bengal reported this form of migration, and women reported that male migration increased their workload. However, female respondents in West Bengal noted that earlier if a woman made a decision and the man disagreed, she would face his criticism. In the absence of male decision-makers women would either consult other male relatives or make decisions by themselves. But now the male partner keeps in regular touch and makes every decision related to the farm over mobile phones. Thus, while communication technology has improved consultative nature of decision-making, overall authority and autonomy of women has remained more-or-less the same irrespective of the physical absence of the male member due to migration.

\subsection{Control over incomes}

Effective power over decision-making within a household is typically linked with control over household income. Especially in rural India, this is distinct from holding the purse strings. Women complained that despite doing all the major work on the farm, including animal rearing, the men keep all the income, be it from farming or dairy. Even though their husbands handed them their income for safekeeping, women rarely ever had the power to spend it themselves. Livestock rearing, in particular looking after dairy cattle, is a job predominantly performed by women, so one may expect them to have more control over the income from it. A higher share of women in West Bengal than in Gujarat (Table 1) had control over income from livestock, but its share in the total family income is one of the lowest. Dairy is one of the major sources of income in Gujarat, and though women perform dairy farming almost exclusively and contribute substantially to milk productivity, they have little control over the income. Milk cooperatives pay on the basis of the fat content in milk and milk collectors find an opportunity to cheat women; so, most women send their husbands to make the sale, and this is how they end up keeping the money.

\section{$<$ Insert Table 1 here $>>$}

\subsection{Gendered land relations}

There exists a positive relation between landownership and an improved economic and social condition for women (Agarwal 1997; Rao 2007). Increasing the proportion of 
farmland owned by women is seen not only as a step towards their empowerment, but also towards improving farm productivity (Rao 2007). In India landholding is considered a proxy for ownership. As per the 2015-16 agricultural census, women operated only $10.3 \%$ of the land in India. The results of our study were broadly in line with this finding: in Gujarat only $4.23 \%$ of the farmland was owned by women (that is, their names were included in government records), while in West Bengal it was slightly higher at $11.22 \%$. This statistically insignificant proportion made it difficult for the present study to address the question of what impact female landownership made on decision-making in rural households.

\section{Women's preference for work on the farm}

Having discussed how women in rural India tend to be left out of decisions related to farm business, despite shouldering the majority of the work, it is important to ask whether they enjoy their work. There is limited literature on this topic, especially in the context of developing countries. While, as pointed out by Agarwal and Agarwal (2017), research has focused mostly on the transition of people from farm to non-farm jobs, especially given the increasing importance of women in the Indian agricultural sector, the question of whether or not they like their work, despite now owning land and farm machinery, is indispensable - with wider implications for any consideration of agriculture in India and its future.

Studies by Birthal et al. (2015) and Agarwal and Agarwal (2017), which have sought to better understand the attitudes of Indian farmers, concluded that female farmers in India are less satisfied with their work than their male counterparts. Whether they liked farming proved to be a difficult question for many of our female respondents, as a simple yes or no was unable to capture their opinion. For some respondents it was difficult to answer because they knew nothing but farming; they never had the opportunity to do something else. Thus, our aim was to gather extended responseswhy they like farming, what they do or not, and why not - to arrive at a conclusion.

While it is reasonable to assume that many respondents who indicated that they did not like farming would choose another occupation if they could, given India's surplus of unskilled labour and their lack of mobility, only few options are available to them. One potential benefit of this line of research then might be that it will provide data for 
designing rural livelihood strategies that fit well with the preferences of the population these are intended to benefit.

A little less than two-thirds of the respondents replied that they liked their job: $61.5 \%$ in Gujarat and 55.3\% in West Bengal (Table 2). These results are in line with those of the NSSO report (59th Round), which shows that in Gujarat 67\% and in West Bengal $54 \%$ of farmers, both men and women, said that they liked farming as an occupation (NSSO 2005). The present survey suggests that around 21.1\% women in Gujarat and $27.8 \%$ women in West Bengal disliked it. Of the total sample $17.4 \%$ and $16.9 \%$ in Gujarat and West Bengal, respectively, replied that it was difficult to tell whether they liked it or not, as they had never known anything but farming.

\section{$<<$ Insert Table 2 here $>>$}

A higher share of women in West Bengal dislike farming possibly because commercialization of agriculture is low in this state and many communities still practice subsistence farming. This is congruent with the findings of Agarwal and Agarwal (2017) that commercial farmers were more satisfied with their jobs than those practising survival agriculture.

Throughout India, as suggested by Birthal et al. (2015) and Agarwal and Agarwal (2017), there is a link between owning land and dissatisfaction with farming. However, the land pattern might vary across regions depending on agro-climatic and hydrogeological factors. Generally dryland areas have a bigger share of land, but these are less fertile and mostly rain-fed. Gujarat is mostly arid and semi-arid; a huge region is under dryland. West Bengal, on the other hand, has a monsoonal, tropical climate with fertile soil. Considering this difference the present study did not find any major link between landholding size and satisfaction of female farmers with their occupation (Table 3). In Gujarat, dissatisfaction among women from large- and mediumlandholding groups was higher than small and marginal landholders. Female sharecroppers-landless households that cultivate by leasing land-did not like farming because of its uncertain nature and poor returns. 
We found that farming is disliked by a higher-than-average proportion of women among SCs in Gujarat and by more SCs and ST women in West Bengal (Table 4). In Gujarat, although ST farmers generally have less land than SCs or the general category, they were not as dissatisfied with farm life. Agarwal and Agarwal (2017) explain this phenomenon as 'adapted preference' (Sen 2000), that is, the severely disadvantaged adapt their expectations and preferences to what is feasible. Unlike existing literature, which states that upper-caste households possess greater resources and generally like farming, this study finds that around $36.2 \%$ of general caste women in Gujarat dislike farming. As most of the youth in the dry northern and western parts of Gujarat migrate, women have to make up for the shortage of labour by working more.

\section{$<<$ Insert Table 4 here $>>$}

Overall, the study shows that the lack of interest in farming is greater in West Bengal than in Gujarat, possibly because farming is not profitable in this state and as a result aspiration of pursuing non-farm activities is higher. The NSSO (59th Round) state-wise analysis of farming as an occupation revealed that $26 \%$ of all farmers in Gujarat and $36 \%$ in West Bengal dislike farming as it is not profitable (NSSO 2005). The analysis of the NSSO unit-level data on farmer's income shows that in 2012-13 farm households' income from cropping averaged at Rs 35,125 in Gujarat and Rs 11,737 in West Bengal. From 2002-3 to 2013-14 the growth rate (compound annual) of farm income in Gujarat increased by $1.4 \%$ compared to a negative growth of $5 \%$ in West Bengal. This led to a negative growth of $1.2 \%$ for total household income in West Bengal against 3.1\% in Gujarat (Ranganathan 2014). This macro scenario of West Bengal's agricultural sector is reflected in the micro setting of its women's dislike for farming.

West Bengal is one of the leading states to produce vegetables: in 2016 the state alone contributed $13 \%$ of the country's total value of fruits and vegetables. Women's involvement in this regard was greater than in any other crop. Most women in this survey reported that their dislike of farming was due primarily to the post-harvest loss of vegetables; the output market is uncertain because cold storages are located far from villages and transport is expensive.

When asked whether having land in their own name would change their attitude towards farming, a clear majority in both states responded positively, but equally widespread 
was their opinion that most female farmers would find it difficult, if not impossible, to achieve this: they cannot afford to buy land. And, in matters related to land tenure, customary law is more important than state law: even if they acquired land, they often did not have a state-recognized title. This makes it much harder for women to be recognized as farmers by the state or society at large, and it can limit their access to agricultural service providers or rural institutions such as cooperative societies.

When women were asked whether they wished to continue farming, even among those who liked farming, $31.1 \%$ in Gujarat and $28.5 \%$ in West Bengal said given a chance they would prefer otherwise (Table 5). A greater proportion of women in the large- and medium-landholding categories than in the small- or marginal-landholding categories expressed their wish to abandon farming (Table 6). While life is generally tougher for small-scale farmers in India, their lack of interest in quitting this occupation can likely be explained by a lack of exposure to other lifestyles, or a pragmatic understanding of the difficult life ahead.

\section{$<<$ Insert Tables 5 and 6 here $>>$}

\section{Implications of the findings}

The present study forces us to confront several questions. As women's labour is getting increasingly concentrated in agriculture we are once again forced to recognize the question of women's landownership, the recognition of their task burdens, their autonomy and authority, and an alternative to farming or better employment. The recognition of women's labour contributions in official statistics, data collection processes, as well as culturally within households and across class-caste contexts would be the first essential step to make the gender agenda more visible.

A lot needs to change with regard to how women's work is counted and measured, and the first step could be defining the 'activity codes'. Feminist scholars have repeatedly emphasized the need to recognize women's unpaid labour to include home-based workers (Hirway 2012; Siddiqui et al. 2017). This study presents the urgent need to recognize women's work in pre-production stages and as 'helpers' or assistants subsidizing family labour into farming. In reporting sex-differentiated activities on the farm, we strongly recommend that sex-differentiated layers of all farm activities be recognized to clarify the extent of women's contribution. Once such dis-aggregated 
data are collected and collated, they will reveal the true extent of the feminization of agricultural labour than what macro-level data show. While aggregated data show women have withdrawn from the workforce, our primary surveys and field experience reveal that women participate in all kinds of farm activities, directly or as a helper. It is only through recognition of women's multitude of roles that official data will be able to acknowledge the true extent of their contributions to agriculture.

Official statistics-gathering exercises note women's farm and non-farm tasks, but overlook their supplementary labours because they cannot be fitted into specific categories. These tasks are small and varied in nature, and consequently do not represent the true extent of women's labour in the field. When a particular task is presented, interpreted, or understood by official statistics as an 'activity status', the coding needs to be broken down to reflect how a particular farm- or non-farm activity is performed in a gendered manner. Such gender-disaggregated data will be beneficial not only for researchers, but also for policymakers by providing the basis to design better rural livelihood strategies that fit well with the preferences of those these are intended to benefit. Recognition of women's activities (and sub-activities) might help in gender-friendly mechanization which instead of displacing women (as reported by Siddiqui et al. 2017) would help in reducing their work burden. Women are rarely considered as primary agency for technology development and mechanization, despite spending longer hours performing heavy, manual work.

Around one-third of the interviewed women strongly noted their unwillingness to be associated with farming labour; they need to contribute even though they 'dislike' farming. Some spoke of their interests and capabilities in starting small businesses, and in preparing and selling home-based packaged food or other products. Besides training and capacity-building, policymakers should facilitate the creation of sustainable income-earning opportunities such as the promotion of agro-processing units located within the rural areas, which women can access despite their poor mobility. With changing times, rural women's aspirations are changing, and thus they should have access to explore different kinds of work where they may find satisfaction.

\section{Acknowledgements}

The authors thank the Australian Research Council (DP 140101682) and the Indian Council of Social Science Research for funding the research project titled 'Farmers of the Future: Challenges of a Feminized Agriculture in India'. The authors express their 
gratitude to Professor Amita Shah for her constructive comments on an earlier version of this paper.

\section{Declaration of interest statement}

The authors declare no conflict of interest.

\section{References}

Abraham, V. 2013. "Missing Labour or Consistent De-Feminisation?” Economic and Political Weekly 48 (31): 99-108.

Agarwal, B. 1981. "Agricultural Mechanization and Labour Use: A Disaggregated Approach.” International Labour Review 12 (1): 115-127.

Agarwal, B. 1985. "Work Participation of Rural Women in the Third World: Some Data and Conceptual Biases." Economic and Political Weekly 20 (51 \& 52): 21-28.

Agarwal, B. 1997. "Bargaining and Gender Relations: Within and Beyond the Household." Feminist Economics 3 (1): 13-58.

Agarwal, B. 2011. "Food Crises and Gender Inequality." DESA Working Paper No. 107, Department of Economic and Social Affairs, United Nations, New York.

Agarwal, B. 2012. "Food Security, Productivity, and Gender Inequality." Working Paper No. 320, Institute of Economic Growth, New Delhi.

Agarwal, B., and A. Agarwal. 2017. "Do Farmers Really Like Farming? Indian Farmers in Transition." Oxford Development Studies 45 (4): 460-478.

Agarwal, T. 2014. "Gender and Caste-based Wage Discrimination in India: Some Recent Evidence.” Journal of Labour Market Research 47 (1): 329-340.

Agrawal, T., and S. Chandrasekhar. 2015. "Short-term Migrants in India: Characteristics, Wages and Work Transition." Working Paper No. 07, Indira Gandhi Institute of Development Research, Mumbai.

Akter, S., P. Rutsaert, J. Luis, N. Me-Htwe, S. S. San, B. Raharjo, and A. Pustika. 2017. "Women's Empowerment and Gender Equity in Agriculture: A Different Perspective from Southeast Asia." Food Policy 69 (C): 270-279. 
Alkire, S., R. Meinzen-Dick, A. Peterman, A. Quisumbing, G. Seymour, and A. Vaz. 2013. “The Women's Empowerment in Agriculture Index.” World Development 52 (C): 71-91.

Anderson, C. L., T. W. Reynolds, and M. K. Gugerty. 2017. "Husband and Wife Perspectives on Farm Household Decision-making Authority and Evidence on Intrahousehold accord in Rural Tanzania." World Development 90 (2): 169-183.

Azad, M. P., M. Prasad, N. Yadav, and S. S. Bhartiya. 1985. "Extent of Participation of Women in Agriculture and Allied Enterprises." Indian Journal of Agricultural Economics 40 (3): 275-276.

Balasubramanian, S. 2013. "Why Micro-credit May Leave Women Worse Off: Nonco-operative Bargaining and the Marriage Game in South Asia." The Journal of Development Studies 49 (5): 609-623.

Baliyan, K. 2016. Women Participation in Agriculture. New Delhi: Mittal Publication. Banerjee, N. 1999. "How Real Is the Bogey of Feminization?" In Gender and Employment in India, edited by T. S. Papola and A. N. Sharma, 299-317. New Delhi: Vikas Publishing House.

Bennet, L. 1992. "Women, Poverty and Productivity in India.” Seminar Paper No. 43, Economic Development Institute, The World Bank, Washington, D.C.

Binswanger-Mkhize, H. P. 2013. "The Stunted Structural Transformation of the Indian Economy Agriculture, Manufacturing and the Rural Non-farm Sector." Economic and Political Weekly 48 (26 \& 27): 5-13.

Birthal, P. S., D. Roy, M. T. Khan, and D. S. Negi. 2015. "Farmers' Preference for Farming: Evidence from a Nationally Representative Farm Survey in India." The Developing Economies 53 (2): 122-134.

Byres, T. J. 1981. "The New Technology, Class formation and Class Action in the Indian Countryside.” The Journal of Peasant Studies 8 (4): 405-454.

Chakravarty, D. 2020. “Hidden from the Data: Landholding Patterns and Women's Low Work Participation Rates in West Bengal, India.” WIDER Working Paper No. 34, UNU-WIDER, Finland.

Chand, R. 2017. “Doubling Farmers' Income: Rationale, Strategy, Prospects and Action Plan.” Policy Paper No. 1, National Institution for Transforming India (NITI Aayog), GOI, New Delhi. 
Chand, R. D., S. Sindhu, and J. L. Kaul. 1985. "Impact of Agricultural Modernization on Labour Use Pattern in Punjab with Special Reference to Women Labour." Indian Journal of Agricultural Economics 40 (3): 252-259.

Chand, R., S. K. Srivastava, and J. Singh. 2017a. "Changing Structure of Rural Economy of India: Implications for Employment and Growth.” Discussion Paper No. 1. NITI Aayog, GOI, New Delhi.

Chand, R., S. K. Srivastava, and J. Singh. 2017b. "Changes in Rural Economy of India, 1971 to 2012: Lessons for Job-led Growth.” Economic and Political Weekly 51 (52): $64-71$.

Chandrasekhar, C. P., and J. Ghosh. 1999. "Indian Economic Reform Process and the Implications of Southeast Asian Crisis." Mimeograph, Employment and Training Department, International Labour Office, Geneva.

Damisa, M. A., and M. Yohanna. 2007. "Role of Rural Women in Farm Management Decision-making Process: Ordered Probit Analysis." Trends in Applied Sciences Research 2 (3): 241-245.

Das, S., S. Jain-Chandra, K. Kochhar, and N. Kumar. 2015. "Women Workers in India: Why So Few Among So Many?” Working Paper No. 55, International Monetary Fund, Asia and Pacific Department. https://www.imf.org/external/pubs/ft/wp/2015/wp1555.pdf. Accessed April 13, 2018. De Schutter, O. 2013. “The Agrarian Transition and the 'Feminization' of Agriculture.” Paper presented at the "Food Sovereignty: A Critical Dialogue International Conference," Yale University, September 14-15. https://www.tni.org/files/download/37_deschutter_2013.pdf. Accessed April 13, 2018. Deere, C. D. 2005. "The Feminization of Agriculture? Economic Restructuring in Rural Latin America.” Occasional Paper No. 1, United Nations Research Institute for Social Development, Geneva.

Doss, C. 2013. "Intrahousehold Bargaining and Resource Allocation in Developing Countries." Policy Research Working Paper No. 6337, The World Bank, Washington, D.C.

Doss, C., S. M. Kim, J. Njuki, E. Hillenbrand, and M. Miruka. 2014. "Women's Individual and Joint Property Ownership: Effects on Household Decision-making." Discussion Paper No. 1347, IFPRI, Washington, D.C.

Duflo, E. 2005. “Gender Equality in Development.” BREAD Policy Paper No. 011, Massachusetts Institute of Technology. 
https://pdfs.semanticscholar.org/d0d6/e82259b976572002eee6351bae39d91 eab0d.pdf . Accessed January 4, 2019.

Duvvury, N. 1989. "Women in Agriculture: A Review of the Indian Literature". Economic and Political Weekly 24 (43): 96-112.

FAO (Food and Agriculture Organization). 2003. "Asia's Women in Agriculture, Environment and Rural Production.” Country papers on Sustainable Development Dimensions, FAO, Bangkok.

Garikipati, S. 2006. "Feminization of Agricultural Labour and Women's Domestic Status: Evidence from Labour Households in India." Research Papers No. 30, University of Liverpool Management School, UK.

Garikipati, S., and S. Pfaffenzeller. 2012. "The Gendered Burden of Liberalization: The Impact of India's Economic Reforms on Its Female Agricultural Labour.” Journal of International Development 24 (7): 841-864.

Gartaula, H., A. Niehof, and L. Visser. 2012. "Shifting Perceptions of Food Security and Land in the Context of Labour Out-migration in Rural Nepal." Food Security 4 (2): 181-194.

GOI. 2018. Economic Survey. New Delhi: Ministry of Finance, GOI.

GOI. 2019. Agricultural Statistics at a Glance 2018. New Delhi: Ministry of Agriculture and Farmers Welfare Department of Agriculture, GOI.

GOWB (Government of West Bengal). 2018. Economic Review 2017-18. Ministry of Statistics and Programme Monitoring, GOWB.

GOG (Government of Gujarat). 2019. Statistical Abstract of Gujarat State 2019. Directorate of Economics and Statistics, GOG.

Headey, D., D. Bezemer, and P. B. Hazell. 2010. “Agricultural Employment Trends in Asia and Africa: Too Fast or Too Slow?” The World Bank Research Observer 25 (1): $57-89$.

Himanshu, and S. Kundu. 2016. "Rural Wages in India: Recent Trends and Determinants." Indian Journal of Labour Economics 59 (2): 217-244.

Hirway, I. 2012. "Missing Labour Force: An Explanation.” Economic and Political Weekly 57 (37): 67-72.

Hirway, I., and S. Jose. 2011. "Understanding Women's Work Using Time-use Statistics: The Case of India." Feminist Economics 17 (4): 67-92.

Horton, S. 1996. Women and Industrialization in Asia. London: Routledge. 
Hyder, A. A., S. Maman, J. E. Nyoni, S. A. Khasiani, N. Teoh, Z. Premji, and S. Sohani. 2005. "The Pervasive Triad of Food Security, Gender Inequity and Women's Health: Exploratory Research from Sub-Saharan Africa." African Health Sciences 5 (4): $328-334$.

Ibrahim, S., and S. Alkire. 2007. "Agency and Empowerment: A Proposal for Internationally Comparable Indicators." Oxford Development Studies 35 (4): 379-403. Jain, D. 1996. "Valuing Work: Time as a Measure." Economic and Political Weekly 31 (43): 48-49.

Kabeer, N. 2001. “Conflicts over Credit.” World Development 29 (1): 63-84.

Kabeer, N. 2016. "Economic Pathways to Empowerment and Active Citizenship: What Does the Data from Bangladesh Tell Us?" The Journal of Development Studies 53 (5): $649-663$.

Kelkar, G., and Y. Wang. 2007. "The Gender Questions and Decent Work: An Analysis of Apparel Industry Worker in China and India." The Indian Journal of Labour Economics 50 (3): 66-89.

Lahiri-Dutt, K. 2014. Experiencing, Coping with Change: Women-headed Farming Households in the Eastern Gangetic Plains. Canberra: Australian Council for International Agricultural Research.

Lastarria-Cornhiel, S. 2006. "Feminization of Agriculture: Trends and Driving Forces." Background Paper for the World Development Report 2008, Rimisp-Latin American Center for Rural Development, Santiago, Chile.

Maharatna, A. 2007. "Population, Economy and Society in West Bengal since the 1970s.” Journal of Development Studies 43 (8): 1381-1422.

Mason, O. K. 2005. “Measuring Women's Empowerment: Learning from Crosscultural Research.” In Measuring Empowerment: Cross-disciplinary Perspectives, edited by D. Narayan , 89-102. Washington, D.C.: World Bank.

Mehrotra, S., and S. Sinha. 2017. "Explaining Falling Female Employment during a High Growth Period.” Economic and Political Weekly 52 (39): 54-62.

Meinzen-Dick, R., A. Quisumbing, J. Berhman, P. Biermayr-Jenzano, V. Wilde, M. Noordeloos, and C. Ragasa. 2010. "Engendering Agricultural Research.” IFPRI Discussion Paper No. 00973, IFPRI, Washington, D.C.

NSSO (National Sample Survey Organization). 2005. Some Aspects of Farming: Situation Assessment Survey of Farmers. Report No. 496. New Delhi: Ministry of Statistics and Programme Implementation, GOI. 
Government of India (NSSO) 2014. Employment and Unemployment Situation in India 2011-12. Report No. 554. New Delhi: Ministry of Statistics and Programme Implementation, GOI.

Pal, S., and S. Haldar. 2016. "Participation and Role of Rural Women in Decisionmaking Related to Farm Activities: A Study in Burdwan District of West Bengal." Economic Affairs 61 (1): 55-63.

Pattnaik, I., K. Lahiri-Dutt, S. Lockie, and B. Prichard. 2018. "The Feminization of Agriculture or the Feminization of Agrarian Distress? Tracking the Trajectory of Women in Agriculture in India." Journal of Asia Pacific Economy 23 (1): 138-155.

PLFS (Periodic Labour Force Survey). 2019. Periodic Labour Force Survey, 2017-18. New Delhi: Ministry of Statistics and Programme Implementation, GOI.

Quisumbing, A. 2003. "Household Decisions, Gender, and Development: A Synthesis of Recent Research.” Washington, D.C.: IFPRI.

Ranganathan, T. 2014. "Farmers' Income in India: Evidence from Secondary Data." New Delhi: Institute of Economic Growth. http://www.iegindia.org//upload/project_studies/1545126735.pdf. Accessed January $20,2019$.

Rao, S. 2011. "Work and Empowerment: Women and Agriculture in South India." Journal of Development Studies 47 (2): 294-315.

Rao, N. 2007. “Custom and the Courts: Ensuring Women's Rights to Land, Jharkhand, India." Development and Change 38 (2): 299-319.

Rawal, V., and P. Saha. 2015. “Women's Employment in India: What Do Recent NSS Surveys of Employment and Unemployment Show?” Monograph No. 1, Society for Social and Economic Research, New Delhi.

Satyavathi, T. C., C. H. Bharadwaj, and P. S. Brahmanand. 2010. "Role of Farm Women in Agriculture: Lessons Learned." Gender Technology and Development 14 (3): 441-449.

Sen, A. K. 2000. Development as Freedom. New Delhi: Oxford University Press.

Shah, A., and B. Harriss-White. 2011. "Resurrecting Scholarship on Agrarian Transformations." Economic and Political Weekly 46 (39): 13-18.

Shah, T., A. Gulathi, P. Hemant, G. Shreedhar, and R. C. Jain. 2009. "Secret of Gujarat's Agrarian Miracle after 2000." Economic and Political Weekly 44 (52): 4555. 
Siddiqui, M. Z., K. Lahiri-Dutt, S. Lockie, and B. Pritchard. 2017. "Reconsidering Women's Work in Rural India: Analysis of NSSO Data, 2004-05 and 2011-12.” Economic and Political Weekly 3 (1): 45-52.

Singh, K. M., R. K. Singh, and A. Kumar. 2013. "Male Worker Migration and Women Empowerment: The Case of Bihar, India." MPRA Paper No. 49385. https://mpra.ub.uni-muenchen.de/49385. Accessed December 4, 2016.

SOFA Team, and C. Doss. 2011. "The Role of Women in Agriculture.” Working Paper No. 02, Agricultural Development Economics Division, Food and Agriculture Organisation, United Nations.

Subhanil, C. 2011. "Employment in India: What Does the Latest Data Show?" Economic and Political Weekly 34 (32): 23-26.

Swain, M., S. S. Kalamkar, and M. Kapadia. 2012. "State of Gujarat Agriculture 201112.” AERC Report 146, Agro-Economic Research Centre, Sardar Patel University Vallabh Vidyanagar, Anand, Gujarat.

Walker, T., and J. Ryan.1990. Village and Household Economies in India's Semi-arid Tropics. Baltimore and London: The Johns Hopkins University Press.

\section{Other Sources}

Business Standard 2019. "Job crisis and note ban: How Bengal is losing its demographic opportunity", April 8.

First Post 2019. "Jute industry in West Bengal faces crisis: Low wages, exploitation leave mill workers facing uncertain future", April 29. 
If you ask us about who practically applies pesticides it is men, but all the preparatory activities surrounding it are performed exclusively by women, be it preparing the mixture, mixing the pesticide with water, helping the man wear the heavy spray container on his shoulders, cleaning the container, and so on. Our labour is not visible and it appears as if men are doing all kind of operations, but in reality we also participate in each and every task that men do on the farm.

Source: Field survey, 2015-16. 


\section{Box 2}

Tulika Rani of Midnapore district in West Bengal has been working on her family farm as an unpaid labour and also as a wage labourer. She is engaged in other nonfarm activities, but government data-collecting agencies do not consider it paid work. Her son goes to the nearby town to sell snacks such as puchka (a fried, crisp, hollow sphere made with wheat flour, filled with a mixture of potato, tamarind, sugar, spices, mint, and chickpeas, and then dipped in flavoured water). Tulika Rani prepares all the ingredients at home. She wakes up early every morning to first prepare the snack for her son. Only then does she go to the field. She says: 'As a mother it my duty to help my child.' While inquiring about who keeps the income, she replies: 'It is my son's income and he keeps it, but occasionally he gives a share for household consumption.' Tulika Rani's son is coded as 'worker' (self-employed), by the government record but her contribution is not recognized anywhere.

Source: Field survey, 2015-16. 


\section{Box 3}

Anilaben Patel of Valsad district of Gujarat has a Bachelor's degree in political science from a state university; her husband has attended only primary school. They have a mango orchard and some land, less than one hectare, in her father-in-law's name. Anilaben is the main worker. She grows paddy, jowar, and other vegetables. Dairy is another major activity. She earns around Rs 4,000 monthly. Her education and interest in farming gave her recognition at home and society, and allowed her to get exposure to the world. She heads various women farmers' groups and a dairy group, and has even travelled to several dairy farms. She says:

I like farming and livestock rearing a lot, that gives me satisfaction, but it involves various kinds of risk, which makes the return unstable. It does not matter on whose name the plot is registered, but the societal mindset that is of importance. Landownership is essential, but education is a must. I have attended several meetings where I was the only woman present and men would underestimate my opinion in such situations. Education is the only option left for women to be empowered as the size of plot is declining and climate change is affecting farm income. In such a situation skills-based livestock rearing is the only available and fruitful occupation.

Source: Field survey, 2015-16. 
Figure 1 Women and their farm activities in Gujarat

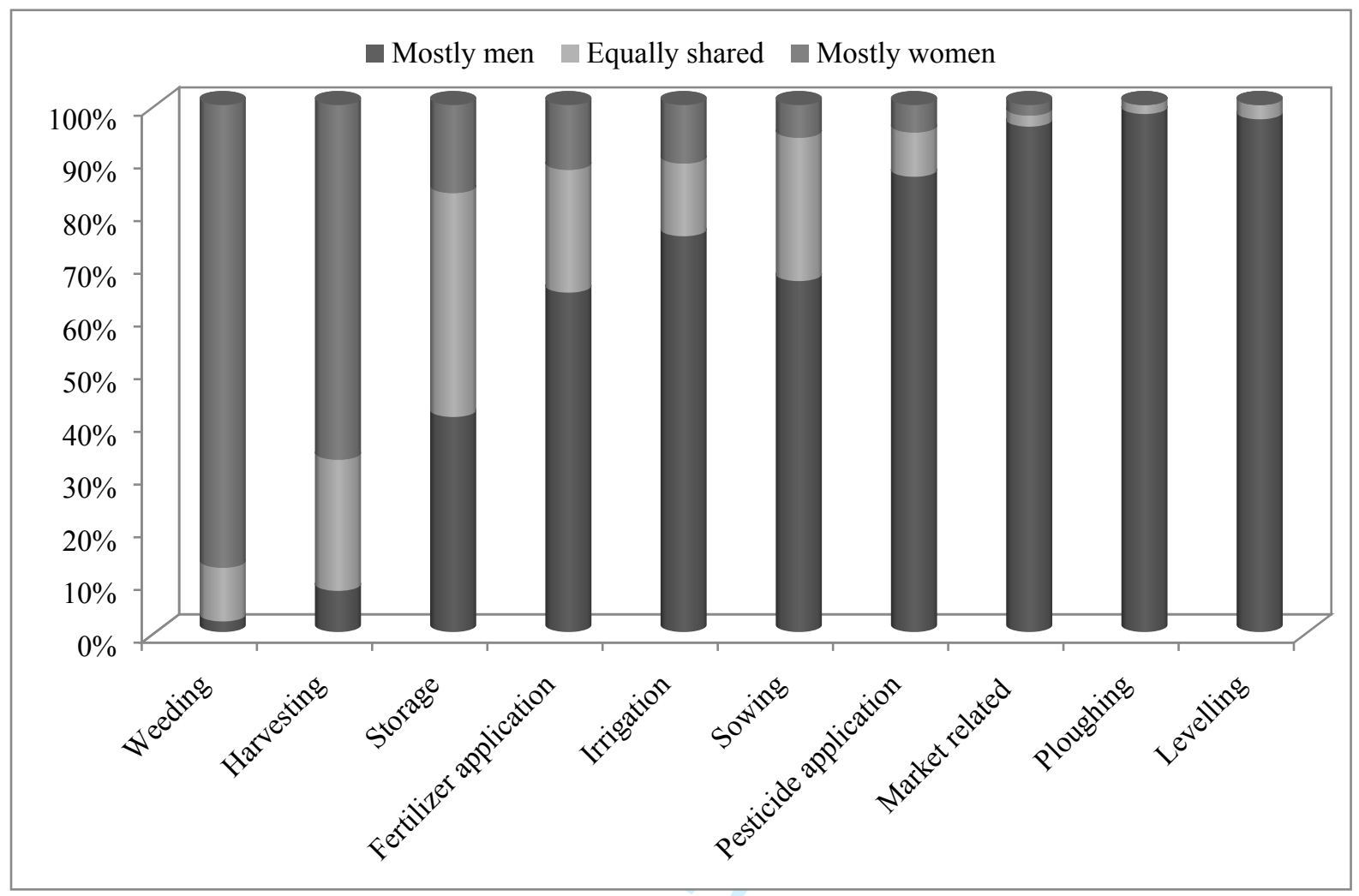

Note: Only major activities are presented here.

Source: Field survey, 2015-16. 
Figure 2 Women and their farm activities in West Bengal

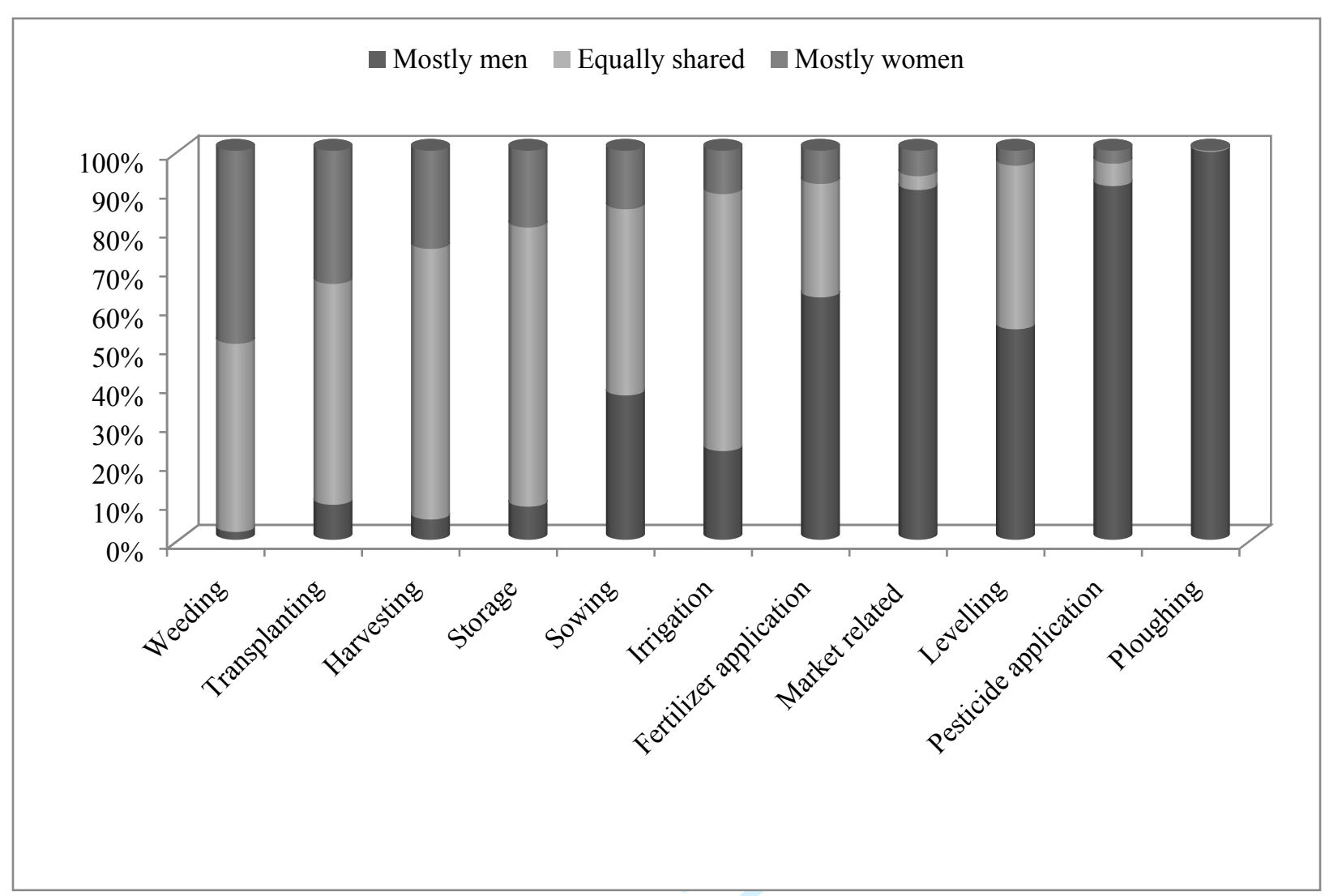

Note: Only major activities are presented here.

Source: Field survey, 2015-16. 
Figure 3 Women's decision-making participation in Gujarat

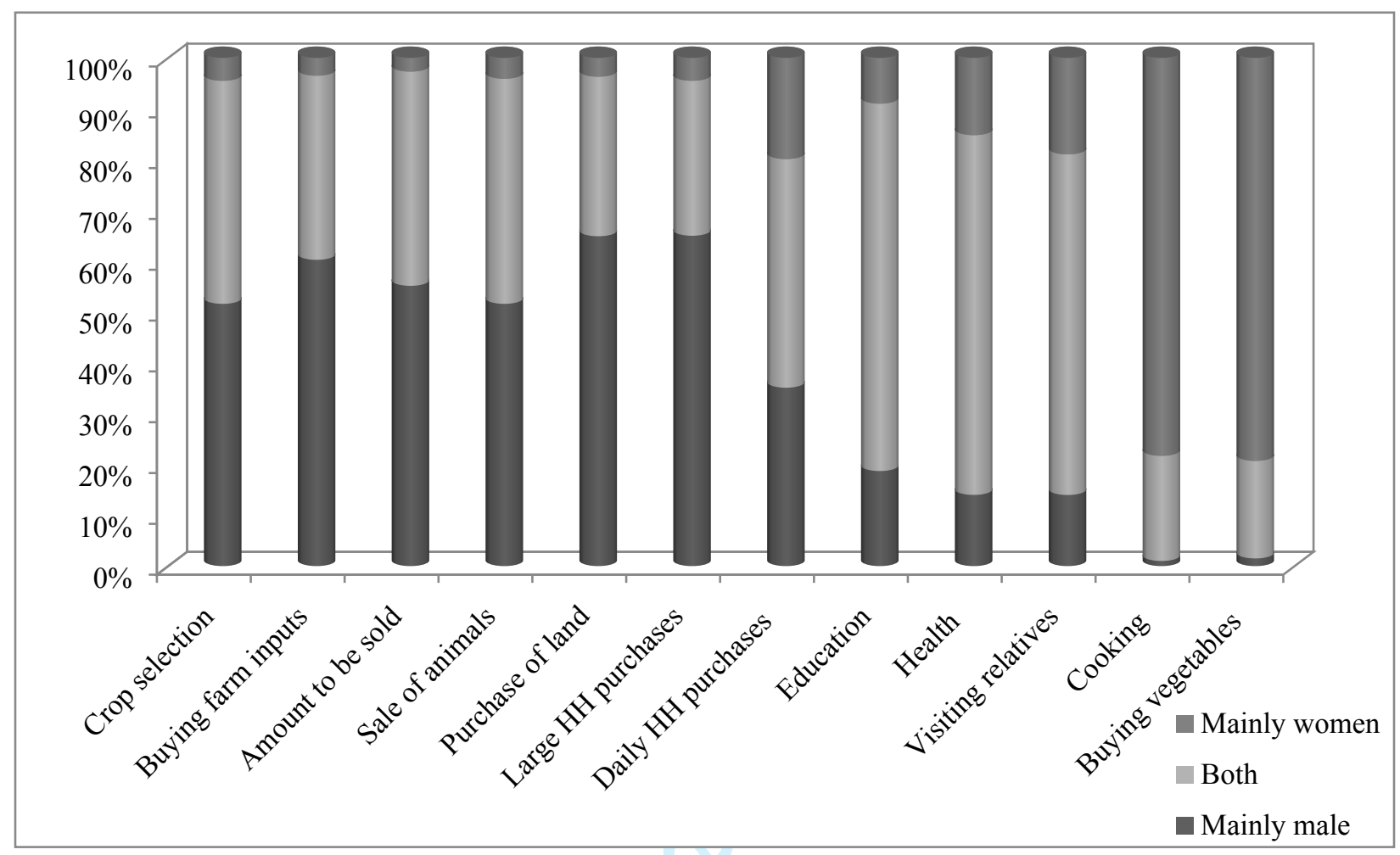

Source: Field survey, 2015-16. 


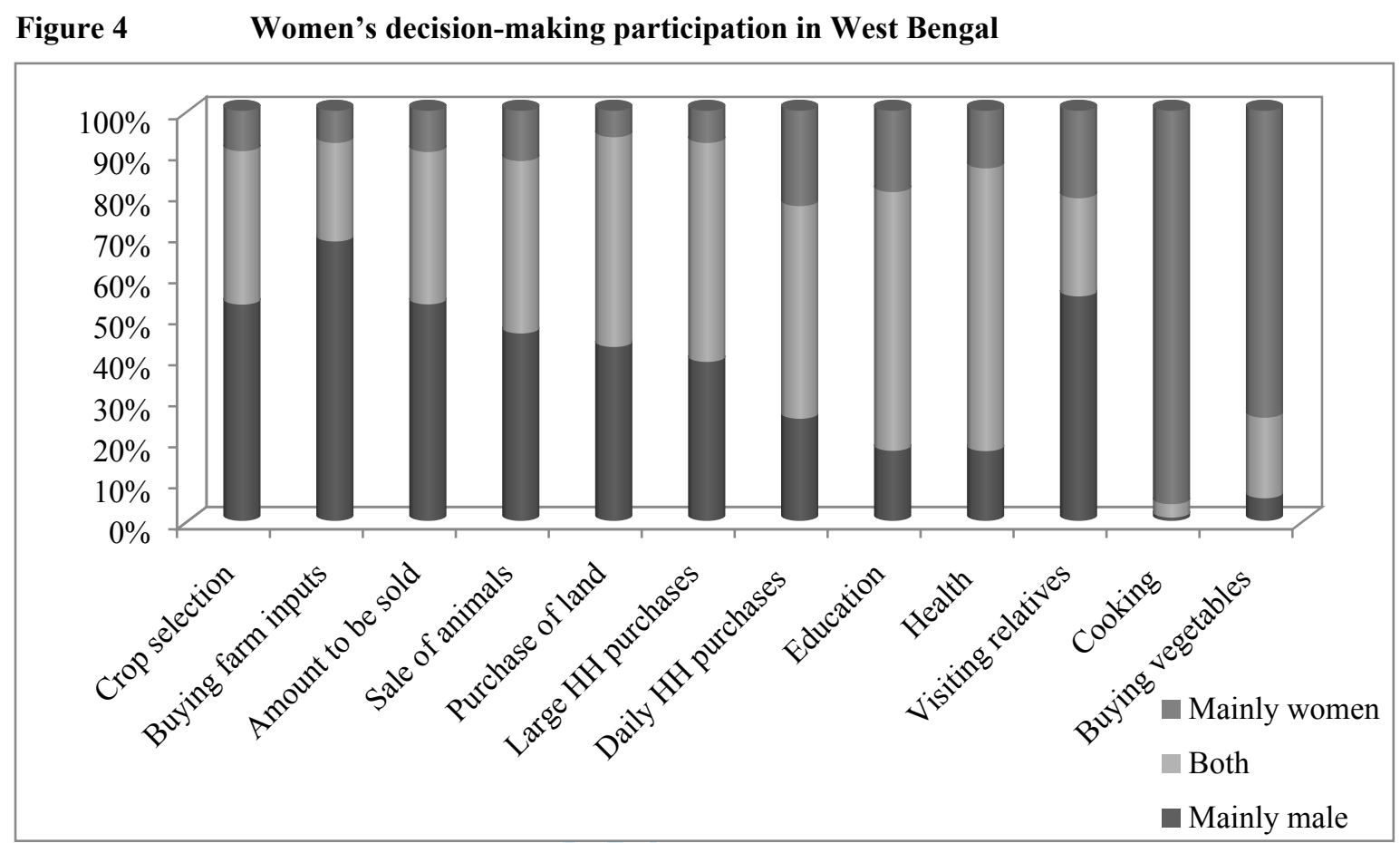

Source: Field survey, 2015-16. 
Table 1 Control over income from farm and dairy

\begin{tabular}{|l|r|r|r|r|}
\hline & \multicolumn{2}{|l|}{ Gujarat } & \multicolumn{2}{l|}{ West Bengal } \\
\hline & Agriculture & Livestock & Agriculture & \multicolumn{1}{l|}{ Livestock } \\
\hline Men & 82.4 & 55.0 & 73.8 & 58.7 \\
\hline Women & 8.5 & 31.7 & 22.4 & 41.0 \\
\hline Both & 9.1 & 13.4 & 3.7 & 0.3 \\
\hline Total & $\mathbf{1 0 0}$ & $\mathbf{1 0 0}$ & $\mathbf{1 0 0}$ & $\mathbf{1 0 0}$ \\
\hline
\end{tabular}

Source: Field survey, 2015-16.

15

16

17

18

19

20

21

22

23

24

25

26

27

28

29

30

31

32

33

34

35

36

37

38

39

40

41

42

43

44

45

46

47

48

49

50

51

52

53

54

55

56

57

58

59

60 
Table 2 Perception of female farmers about farming, region-wise $(\mathrm{N}=\mathbf{6 , 0 0 5})$

\begin{tabular}{|l|l|l|l|l|}
\hline & Like & Dislike & No Definite Answer* & Total \\
\hline Patan & 59.3 & 29.1 & 11.6 & 100 \\
\hline Rajkot & 63.6 & 16.8 & 19.6 & 100 \\
\hline Valsad & 56.8 & 27.5 & 15.8 & 100 \\
\hline Panchmahal & 64.6 & 14.7 & 20.7 & 100 \\
\hline Gujarat & $\mathbf{6 1 . 5}$ & $\mathbf{2 1 . 1}$ & $\mathbf{1 7 . 4}$ & $\mathbf{1 0 0}$ \\
\hline Midnapore & 56.7 & 25.1 & 18.2 & 100 \\
\hline Cooch Behar & 53.0 & 30.2 & 16.8 & 100 \\
\hline Purulia & 58.6 & 24.1 & 17.2 & 100 \\
\hline Malda & 54.0 & 30.5 & 15.5 & 100 \\
\hline West Bengal & $\mathbf{5 5 . 3}$ & $\mathbf{2 7 . 8}$ & $\mathbf{1 6 . 9}$ & $\mathbf{1 0 0}$ \\
\hline Total sample in both states & $\mathbf{5 8 . 6}$ & $\mathbf{2 4 . 2}$ & $\mathbf{1 7 . 2}$ & $\mathbf{1 0 0}$ \\
\hline
\end{tabular}

Notes: Data from the house listing of all 16 villages.

* 'No Definite Answer' includes: 'We do not know the difference between like or dislike as nothing works according to our wish', 'There is no other option so we are in agriculture', and 'We do not know anything apart from agriculture, so difficult to say whether we like it or not'.

Source: Field survey, 2015-16. 
Table 3 Perception of female farmers about farming, land-category-wise $(N=6,005)$

\begin{tabular}{|c|c|c|c|c|c|c|c|c|}
\hline \multirow{3}{*}{ Land Category } & \multicolumn{4}{|l|}{ Gujarat } & \multicolumn{4}{|l|}{ West Bengal } \\
\hline & \multirow[b]{2}{*}{$\begin{array}{l}\text { Share of } \\
\text { landholding } \\
\text { size }\end{array}$} & \multicolumn{3}{|c|}{ Do you like farming? } & \multirow[b]{2}{*}{$\begin{array}{l}\text { Share of } \\
\text { landholding } \\
\text { size }\end{array}$} & \multicolumn{3}{|c|}{ Do you like farming? } \\
\hline & & Like & Dislike & $\begin{array}{l}\text { No definite } \\
\text { answer* }\end{array}$ & & Like & Dislike & $\begin{array}{l}\text { No } \\
\text { definite } \\
\text { answer }\end{array}$ \\
\hline Marginal & 52.1 & 64.5 & 14.6 & 20.9 & 72.8 & 56.7 & 26.6 & 16.7 \\
\hline Small & 25.5 & 64.0 & 22.6 & 13.5 & 4.5 & 49.2 & 27.4 & 23.4 \\
\hline Medium & 3.9 & 60.8 & 25.6 & 13.6 & - & - & - & - \\
\hline Large & 1.5 & 70.2 & 23.4 & 6.4 & - & - & - & - \\
\hline $\begin{array}{l}\text { Landless } \\
\text { (sharecroppers } \\
\text { and cultivating in } \\
\text { forest land) }\end{array}$ & 11.3 & 38.3 & 50.5 & 11.2 & 22.7 & 52.1 & 31.6 & 16.2 \\
\hline $\begin{array}{l}\text { Joint with larger } \\
\text { family }\end{array}$ & 5.8 & 66.8 & 12.8 & 20.3 & - & - & - & - \\
\hline Total & 100 & 61.5 & 21.1 & 17.4 & 100 & 55.3 & 27.8 & 16.9 \\
\hline
\end{tabular}

Notes: Data from the house listing of all 16 villages.

* Same as explained in Table 2.

Source: Field survey, 2015-16. 
Table 4 Perception of female farmers about farming, social-category-wise $(N=6,005)$

\begin{tabular}{|l|l|l|l|l|l|l|l|l|}
\hline Caste & \multicolumn{2}{|l|}{ Gujarat } & \multicolumn{2}{l|}{ West Bengal } \\
\hline & $\begin{array}{l}\text { Share of caste } \\
\text { groups } \\
\text { surveyed }\end{array}$ & Like & Dislike & $\begin{array}{l}\text { No definite } \\
\text { answer* }\end{array}$ & $\begin{array}{l}\text { Share of caste } \\
\text { groups } \\
\text { surveyed }\end{array}$ & Like & Dislike & $\begin{array}{l}\text { No } \\
\text { definite } \\
\text { answer }\end{array}$ \\
\hline General & 13.8 & 53.5 & 36.2 & 10.3 & 22.9 & 57.4 & 24.6 & 18.0 \\
\hline ST & 28.6 & 64.0 & 14.9 & 21.1 & 19.0 & 56.7 & 29.2 & 14.0 \\
\hline SC & 5.2 & 53.0 & 33.3 & 13.7 & 40.5 & 52.5 & 29.7 & 17.8 \\
\hline OBC & 52.5 & 63.1 & 19.2 & 17.7 & 17.5 & 57.4 & 26.1 & 16.5 \\
\hline Total & $\mathbf{1 0 0 . 0}$ & $\mathbf{6 1 . 5}$ & $\mathbf{2 1 . 1}$ & $\mathbf{1 7 . 4}$ & $\mathbf{1 0 0 . 0}$ & $\mathbf{5 5 . 3}$ & $\mathbf{2 7 . 8}$ & $\mathbf{1 6 . 9}$ \\
\hline
\end{tabular}

Note: * Same as explained in Table 2.

Source: Field survey, 2015-16. 
Table 5 Future preference of female farmers

\begin{tabular}{|l|l|l|l|l|l|}
\hline \multicolumn{5}{|c|}{ Gujarat } & \multicolumn{3}{c|}{ West Bengal } \\
\hline \multicolumn{5}{|c|}{ Would you want to continue farming in future? } \\
\hline District & Yes & No & District & Yes & No \\
\hline Patan & 67.3 & 32.7 & Midnapore & 67.1 & 32.9 \\
\hline Valsad & 74.4 & 25.6 & Cooch Behar & 72.2 & 27.8 \\
\hline Rajkot & 68.8 & 31.3 & Purulia & 71.5 & 28.1 \\
\hline Panchmahal & 75.3 & 24.7 & Malda & 70.8 & 28.9 \\
\hline Total & $\mathbf{6 9 . 9}$ & $\mathbf{3 1 . 1}$ & Total & $\mathbf{7 2 . 4}$ & $\mathbf{2 8 . 5}$ \\
\hline & Do you want to perform livestock activities in future? & \\
\hline District & Yes & No & District & Yes & No \\
\hline Patan & 67.7 & 32.3 & Midnapore & 82.3 & 17.7 \\
\hline Valsad & 80.1 & 19.9 & Cooch Behar & 84.8 & 15.2 \\
\hline Rajkot & 78.4 & 21.6 & Purulia & 91.6 & 8.4 \\
\hline Panchmahal & 87.5 & 12.5 & Malda & 89.6 & 10.4 \\
\hline Total & $\mathbf{7 9 . 6}$ & $\mathbf{2 0 . 4}$ & Total & $\mathbf{8 6 . 8}$ & $\mathbf{1 3 . 2}$ \\
\hline
\end{tabular}

Source: Field survey, 2015-16. 
Table 6 Future preference of female farmers by landholding

\begin{tabular}{|l|l|l|l|l|l|l|}
\hline $\begin{array}{l}\text { Would you want to continue } \\
\text { farming in future? }\end{array}$ & \multicolumn{2}{l}{ Gujarat } & \multicolumn{3}{l}{ West Bengal } \\
\hline & Yes & No & Total & Yes & No & Total \\
\hline Marginal & 76.9 & 23.1 & 100 & 71.8 & 28.2 & 100 \\
\hline Small & 75.7 & 24.3 & 100 & 75.8 & 24.2 & 100 \\
\hline Medium & 68.8 & 31.2 & 100 & - & - & - \\
\hline Large & 74.5 & 25.5 & 100 & - & - & - \\
\hline Landless (lease-in and forest land) & 40.2 & 59.8 & 100 & 64.9 & 35.1 & 100 \\
\hline Joint farmer & 73.3 & 26.7 & 100 & & & \\
\hline Total & $\mathbf{6 9 . 9}$ & $\mathbf{3 1 . 1}$ & 100 & $\mathbf{7 2 . 4}$ & $\mathbf{2 8 . 5}$ & 100 \\
\hline
\end{tabular}

Source: Field survey, 2015-16. 